\title{
The Rotterdam Study: objectives and design update
}

\author{
Albert Hofman · Monique M. B. Breteler • Cornelia M. van Duijn • \\ Gabriel P. Krestin - Huibert A. Pols • Bruno H. Ch. Stricker • \\ Henning Tiemeier • André G. Uitterlinden · Johannes R. Vingerling • \\ Jacqueline C. M. Witteman
}

Received: 27 August 2007 / Accepted: 5 October 2007/Published online: 23 October 2007

(C) Springer Science+Business Media B.V. 2007

\begin{abstract}
The Rotterdam Study is a prospective cohort study ongoing since 1990 in the city of Rotterdam in the Netherlands. The study targets cardiovascular, neurological, ophthalmological and endocrine diseases. As of 2008 about 15,000 subjects aged 45 years or over comprise the Rotterdam Study cohort. The findings of the Rotterdam Study have been presented in some 600 research articles and reports (see http://www.epib.nl/rotterdamstudy). This article gives the reasons for the study and its design. It also presents a summary of the major findings and an update of the objectives and methods.
\end{abstract}

Keywords Alzheimer disease - Cohort study .

Dementia - Diabetes · Genome wide analysis · Glaucoma · Heart failure - Macular degeneration .

Myocardial infarction - Osteoporosis · Parkinson disease · Pharmaco-epidemiology $\cdot$ Stroke

A. Hofman $(\bowtie) \cdot$ M. M. B. Breteler · C. M. van Duijn .

H. A. Pols - B. H. Ch. Stricker - H. Tiemeier ·

A. G. Uitterlinden · J. R. Vingerling · J. C. M. Witteman Department of Epidemiology \& Biostatistics, Erasmus Medical Center, Rotterdam, The Netherlands

e-mail: a.hofman@erasmusmc.nl

G. P. Krestin

Department of Radiology, Erasmus Medical Center, Rotterdam, The Netherlands

H. A. Pols - B. H. Ch. Stricker - A. G. Uitterlinden Department of Internal Medicine, Erasmus Medical Center, Rotterdam, The Netherlands

J. R. Vingerling

Department of Ophthalmology, Erasmus Medical Center,

Rotterdam, The Netherlands

\section{Introduction}

The Rotterdam Study was designed in the mid-1980s as a response to the demographic changes that were leading to an increase of the proportion of elderly people in most populations [1]. It was clear that this would produce a strong rise in elderly people living with diseases, as most diseases cluster at the end of life, and that to discover the causes of diseases in the elderly one would have to study risk factors of those diseases [2]. A major approach to finding causes is the prospective follow-up study, which has proven quite effective in finding causes of heart disease and cancer. Remarkably, in the 1980s there were hardly any follow-up studies focussing on the elderly.

\section{The design of the Rotterdam Study}

The basic design of the study was straight-forward: a prospective cohort study among 7,983 persons living in the well-defined Ommoord district in the city of Rotterdam in the Netherlands (78\% of 10,215 invitees). They were all 55 years of age or over and the oldest participant at the start was 106 years [3]. The study started with a pilot phase in the second half of 1989. From January 1990 onwards participants were recruited for the Rotterdam Study. Figure 1 gives a diagram of the various cycles of the study.

In 1999, 3,011 participants (out of 4,472 invitees) who had become 55 years of age or moved into the study district since the start of the study were added to the cohort.

In 2006, a further extension of the cohort was initiated in which about 6,000 subjects aged 45-54 years, living in the Ommoord district, were invited (expected number of participants about 4,000). By the end of 2008, the Rotterdam Study is therefore expected to comprise about 15,000 subjects aged 45 years or over. 


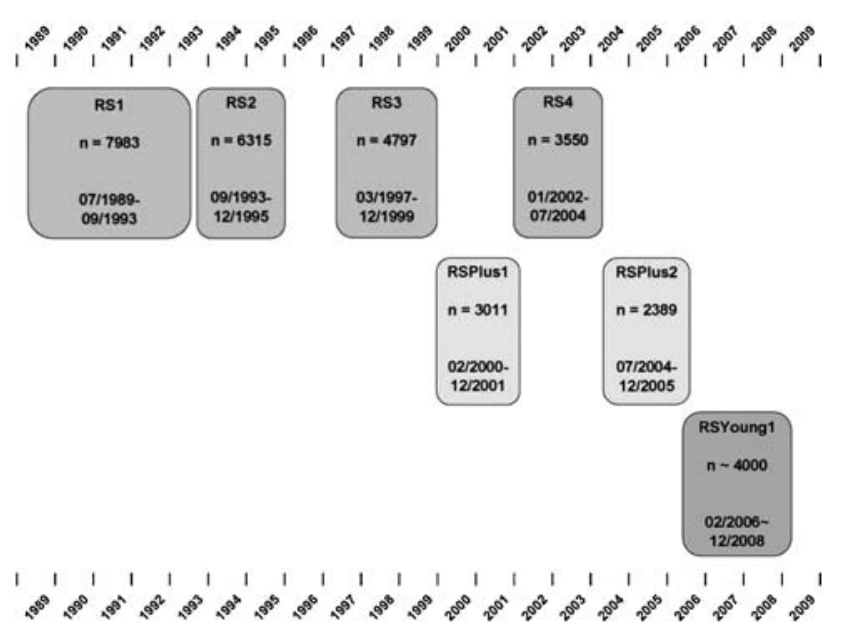

Fig. 1 Diagram of examination cycles of the Rotterdam Study (RS). RS1 refers to the baseline examination of the original cohort (pilot phase 07/1989-12/1989; cohort recruitment 01/1990-09/1993). RS2, RS3 and RS4 refer to re-examination of the original cohort members. RSPlus1 refers to the extension of the cohort with persons in the study district that became 55 years since the start of the study or those of 55 years or over that migrated into the study district. RSPlus 2 refers to the re-examination of the extension cohort. RSYoung1 refers to the baseline examination of all persons aged 45 and over living in the study district that had not been examined (i.e. mainly comprising those aged $45-55$ years)

The participants were all examined in some detail at baseline. They were interviewed at home $(2 \mathrm{~h})$ and then had an extensive set of examinations (a total of $5 \mathrm{~h}$ ) in a specially built research facility in the centre of their district. These examinations focussed on possible causes of invalidating diseases in the elderly in a clinically state-ofthe-art manner, as far as the circumstances allowed. The emphasis was put on imaging (of heart, blood vessels, eyes, skeleton and later brain) and on collecting bodily fluids that enabled further in-depth molecular and genetic analyses. These examinations were repeated every $3-$ 4 years in characteristics that could change over time. And so we had examination cycles from 1990 to 1993 , from 1993 to 1995 , from 1997 to 1999 , from 2000 to 2001, from 2002 to 2004, from 2004 to 2005 and from 2006 to 2008 (Fig. 1).

The participants in the Rotterdam Study are followed for a variety of diseases that are frequent in the elderly (and many are also in the not so elderly): coronary heart disease, heart failure and stroke, Parkinson disease, Alzheimer disease and other dementias, depression and anxiety disorders, macular degeneration and glaucoma, diabetes mellitus and osteoporosis.

The Rotterdam Study has been approved by the institutional review board (Medical Ethics Committee) of the Erasmus Medical Center and by the review board of the Netherlands Ministry of Health, Welfare and Sports. The approval has been renewed every 5 years. Separate approval has been obtained for the introduction of major new elements in the study (e.g. MRI investigations).

In the remainder of this article the objectives and major findings will be presented with an update of the methods for cardiovascular diseases, neurological diseases, ophthalmologic diseases, psychiatric diseases, endocrine diseases, as well as for genetic and for pharmaco-epidemiologic studies.

\section{Cardiovascular diseases}

\section{Objectives}

Research on the epidemiology of cardiovascular diseases focuses on three primary areas of interest: studies on risk factors for atherosclerosis and coronary heart disease, studies on the detection of subjects at high risk of coronary heart disease, and studies on cardiovascular conditions in older age.

Two groups of putative risk factors for atherosclerosis and coronary heart disease are included. The first are endocrine factors, including estrogens and androgens, insulin and insulin-like growth hormone I, and thyroid gland and adrenal gland hormones. The second group contains factors involved in haemostasis, inflammation and endothelial function. Research also focuses on genetic factors in these areas in relation to risk of coronary heart disease.

The ability of classical cardiovascular risk factors to identify subjects at high risk of coronary heart disease is limited. Risk stratification may be improved when based on the presence of atherosclerosis. To this end, repeated measurements of non-coronary atherosclerosis and measurements of coronary, carotid and aortic arch calcification have been included in the study.

Another line of research focuses on cardiovascular diseases in the elderly that are in large part the consequence of ischemic heart disease, like heart failure and atrial fibrillation. An important topic in this area is the early diagnosis of heart failure using echocardiographic assessment of asymptomatic systolic and diastolic dysfunction of the left ventricle. Atrial fibrillation is another major chronic condition frequent at older age. Examination of the determinants and prognosis of atrial fibrillation is part of this research line.

\section{Major findings}

Findings on determinants of atherosclerosis and coronary heart disease include the relation between hypothyroidism 
and myocardial infarction [4] and the association of genetic variation in the estrogen receptor alpha gene with risk of myocardial infarction in women [5]. The study demonstrated that high levels of CRP [6] and lipoproteinassociated phospholipase A2 activity [7] were associated with risk of coronary heart disease and stroke. Genetic findings in this area include a positive association of coronary heart disease with genetic variation in the complement factor $\mathrm{H}$ gene [8] but not with variation in the CRP gene [6].

The study showed that carotid intima-media thickness and plaques measured by ultrasound, the ankle-arm index, and aortic calcification detected by X-ray are independent predictors of risk of coronary heart disease [9]. The study also showed that vessel wall stiffness, as measured by aortic pulse wave velocity (PWV), improved prediction of cardiovascular disease beyond the classical risk factors [10]. The Rotterdam Study was the first to publish results from population-based research on the predictive value for coronary heart disease of coronary calcification assessed by electron-beam CT [11].

The study enabled accurate assessment of the incidence and lifetime risk of heart failure and atrial fibrillation in an elderly population $[12,13]$. It was shown that atherosclerosis and inflammation are also involved in these conditions [14, 15].

\section{Methods update}

Repeated measures of non-coronary atherosclerosis included carotid intima-media thickness and plaques by ultrasound, the ankle-arm index and aortic calcification by X-ray [9]. Electron-beam CT and multi-detector CT were used to accurately quantify calcification in the coronary, aortic arch and carotid arteries [11]. In the second additional cohort of the Rotterdam Study (RS Young1, see Fig. 1), the measurement of plaque vulnerability with highresolution MRI of the carotid arteries will be added. Other outcome measures include electrocardiography, echocardiography and measures of vessel wall stiffness (PWV and carotid distensibility) [10].

Determinants were assessed by physical examinations, collection of blood samples, and by questionnaires and interview. The role of genetic factors is studied using the candidate gene approach and more recently the genome wide association study.

Clinical cardiovascular outcomes are collected during our continuous follow-up and include non-fatal myocardial infarction and cardiac death, revascularizations, heart failure and atrial fibrillation. The methods of diagnosis of these outcomes have been described in previous papers $[6,12,13]$.

\section{Neurological diseases}

\section{Objectives}

Neuroepidemiologic research in the Rotterdam Study focuses on the frequency, etiology and early recognition of the most frequent neurologic diseases in the elderly, including dementia (in particular Alzheimer disease), Parkinson disease and stroke. In neurodegenerative and cerebrovascular disorders clinical symptoms typically become manifest late in the disease course, the occurrence of clinical disease does not reflect the underlying spectrum of disease-related pathology, and most of the clinical syndromes are etiologically heterogeneous. Therefore, an additional research focus is on the causes and consequences of pre-symptomatic brain pathology that can be assessed with non-invasive imaging modalities.

\section{Major findings}

Neurodegenerative and cerebrovascular diseases are highly frequent in the elderly. The prevalence increases from age 55 to 65 years to age 90 years and above from less than $1 \%$ to over $40 \%$ for dementia [16], from less than $0.5 \%$ to more than $4 \%$ for Parkinson disease [17], and from approximately $1 \%$ to nearly $10 \%$ for stroke. The incidence figures follow this pattern of a strong increase with age over the entire age range, with the age-specific incidence of dementia being identical for men and women at least until the age of 85 [18] but with men having a higher agespecific incidence of both stroke and Parkinson disease than women throughout the age range $[19,20]$.

Vascular pathology and vascular risk factors are associated with worse cognitive performance [21], which also translates in people with vascular pathology or risk factors for vascular disease having an increased risk of dementia, including Alzheimer disease [22]. Moreover, several life style factors are associated with the risk of dementia and Alzheimer disease [23-25], suggesting that onset of dementia may at least partly be delayed or prevented. Commonly used drugs may have a role in this [26].

The classical risk factors for stroke also predict risk of stroke in the Rotterdam Study [27]. More recently identified risk factors, including inflammatory markers, may be etiologically relevant but thus far add little to the identification of people at risk [28]. Possibly underlying this is that a large amount of stroke goes clinically undetected [29]. Nearly $20 \%$ of elderly people have at least one silent brain infarct, and thereby a nearly fourfold increased risk of clinical stroke, a more than doubled risk of dementia including Alzheimer disease, and an increased risk of depression [29].

Neuroimaging reveals that brain pathology is widespread [30] and can go clinically undetected for a long 
time. In addition to the silent infarcts, many apparently healthy elderly have ischemic changes in their cerebral white matter that are associated with an increased risk of dementia, stroke and depression [31]. Also brain atrophy, especially of the hippocampus, is already present years before onset of even the earliest sign of cognitive impairment or subjective complaints [32]. This emphasizes the need to shift the attention in etiologic research of neurodegenerative and cerebrovascular disease to the causes of pre-symptomatic and underlying brain changes.

\section{Methods update}

\section{Assessment of dementia and Alzheimer disease}

In the baseline and follow-up examinations participants undergo an initial screen for dementia with the Mini Mental State Examination (MMSE) and the Geriatric Mental Schedule (GMS), followed by an examination and informant interview with the Cambridge Examination for Mental Disorders of the Elderly (CAMDEX) in screenpositives (MMSE $<26$ or GMS $>0$ ), and subsequent neurological, neuropsychological and neuroimaging examinations [16, 18]. Of subjects who cannot be reexamined in person, information is obtained from the GPs and the regional institute for outpatient mental health care. A consensus panel makes the final diagnoses in accordance with standard criteria (DSM-III-R criteria; NINCDS-ADRDA; NINDS-AIREN).

\section{Assessment of parkinsonism and Parkinson disease}

Participants are screened in the baseline and follow-up examinations for cardinal signs of parkinsonism (resting tremor, rigidity, bradykinesia or impaired postural reflexes). Persons with at least one sign present are examined with the Unified Parkinson Disease Rating Scale and a further neurologic exam. Parkinson disease is diagnosed if two or more cardinal signs are present in a subject not taking antiparkinsonian drugs, or if at least one sign has improved through medication, and when all causes of secondary parkinsonism (dementia, use of neuroleptics, cerebrovascular disease, multiple system atrophy or progressive supranuclear palsy) can be excluded [17, 19].

\section{Assessment of stroke and stroke subtypes}

History of stroke at baseline was assessed through interview and verified in medical records. Putative incident strokes get identified through the linkage of the study database with files from general practitioners, the municipality, and nursing home physicians' files, after which additional information (including brain imaging) is collected from hospital records. A panel discusses all potential strokes and subclassifies strokes into ischemic, hemorrhagic or unspecified [20, 28].

\section{Assessment of cognitive function}

Global cognitive function is measured through the Mini Mental State Examination (MMSE) in all surveys. From the third survey onwards we added a 30 min test battery that was designed to assess executive function and memory function, and which includes a Stroop test, a Letter Digit Substitution Task, a Word Fluency Test, and a 15 words Word List Learning test.

Rotterdam Scan Study: brain imaging within the Rotterdam Study

In 1991, a random sample of 111 participants underwent axial T2-weighted magnetic resonance (MR) imaging to assess presence and severity of white matter lesions [33]. In 1995, a random sample of 563 non-demented participants underwent brain MR imaging in the context of the Rotterdam Scan Study. The scanning protocol included series of axial proton-density, T2-weighted and T1-weighted images, as well as a high-resolution 3D-HASTE sequence [31]. From August 2005 onwards, a dedicated 1.5 Tesla scanner is operational in the research centre of the Rotterdam Study, and brain imaging is performed in all study participants without contra-indications. The scanning protocol includes 4 high-resolution axial sequences (3D T1-weighted; 2D PDweighted; 2D FLAIR; and 3D T2* GRE), 2D phase-contrast imaging, and diffusion tensor imaging (DTI).

\section{Psychiatric diseases}

\section{Objectives}

The aim of the psychiatric research in the Rotterdam Study is to investigate the determinants, correlates and consequences of common psychiatric problems in the elderly. The focus has been on depressive disorders but anxiety disorders, sleep disturbances and complicated grief are also being studied.

\section{Major findings}

The one-month prevalence of both major and minor depression at baseline was $1.5 \%$, the prevalence of anxiety disorder was $8.2 \%$. 
We found evidence for the vascular depression hypothesis. More severe coronary and extra-coronary atherosclerosis were associated with a higher prevalence of depression, as were cerebral haemodynamic changes [34, 35]. However, we could not rule out that earlier depressive episodes may have contributed to the development of atherosclerosis. Moreover, our data did not support a specific symptom profile of vascular depression as previously defined [36].

Most of our studies of nutritional and metabolic factors provided no support for an etiological role in depression. Folate deficiency, homocysteine, fatty acid ratio (omega-6/ omega-3) and vitamin $\mathrm{E}$ had little or no effect on the risk of depression after control for health and health related behaviour [37-39]. In contrast, low levels of vitamin B12 and high levels of inflammatory protein IL-6 convey a strong risk for depression, although the latter effect may be confined to high-risk groups [40].

Several SNPs have been investigated, mostly with negative results. However, we found that an ER-alpha polymorphism had a substantial effect on anxiety but not on depression in women [41].

\section{Methods update}

In the first years of the Rotterdam Study psychiatric data collection was very limited. However, from the third examination onwards, which began in 1997 (see Fig. 1), depressive symptoms and disorders are have been ascertained in all participants. The 4,603 participants with valid depression scores in this examination thus constitute the baseline population for longitudinal studies of depression. Because assessment of anxiety disorders, sleeping disturbances and complicated grief were added in the fourth examination, they can currently be studied only crosssectionally.

\section{Assessment of determinants}

Psychiatric research in the Rotterdam Study focuses on biological risk factors. The vascular depression hypothesis was tested with different measures of atherosclerosis, arterial stiffness and cerebral blood flow [34, 35]. We also examined whether blood levels of vitamins and fatty acids, immune parameters, and markers of folate metabolism increased the likelihood of depression [37-40]. In one ongoing project, diurnal patterns of cortisol secretion are related to psychiatric and other disorders. Studies of genetic polymorphisms and brain morphology are underway. Current data collection includes a dexamethasone suppression test to measure hypothalamic-pituitary-adrenal axis activity in all participants, which is unique in a population-based study.

\section{Assessment of outcomes}

Depression is assessed using a two step procedure. First, participants completed the Center for Epidemiologic Studies Depression scale (CES-D) during the home interview to measure self-reported depressive symptoms [42]. As a second step, screen positive subjects, who scored above a well-established CES-D cut-off of 20 points, have a psychiatric interview using the Present State Examination (PSE/SCAN) [43]. This semi-structured interview is conducted by a clinician and yields DSM-IV diagnoses including major and minor depression and dysthymia.

The following anxiety disorders are assessed with a slightly adapted Munich version of the Composite International Diagnostic Interview: generalized anxiety disorder, specific and social phobia, agoraphobia without panic disorder, and panic disorder [44]. Sleep quality and disturbance is measured with the Pittsburgh Sleep Quality Index. In addition, sleep duration and fragmentation are assessed with actigraphy, a method that infers wakefulness and sleep from the presence or absence of limb movement [45]. The Inventory of Complicated Grief is used to identify traumatic grief [46]. This is a condition distinct from normal grief and bereavement-related depression, characterized by symptoms like disbelief about the death and searching for the deceased.

\section{Ophthalmologic diseases}

\section{Objectives}

The primary objectives of the ophthalmological part of the Rotterdam Study are to study frequency and risk factors of common and invalidating eye diseases with emphasis on age-related macular degeneration (AMD) and primary open angle glaucoma (POAG). Another line of research focuses on the associations between retinal vessel abnormalities and cardiovascular and neurologic diseases.

\section{Major findings}

AMD was the main cause of blindness in the high agegroup [47]. Major risk factors that were found for AMD are smoking, atherosclerosis, hyperopia [48-50]. The APO-E $\varepsilon-4$ allele showed an inverse association with AMD [51]. First-degree relatives of patients with late ARM developed ARM at an increased rate at a relatively young age [52]. The heterogeneity of genetic risk among AMD families is considerable, and the proportion of high-risk families is relatively small [53]. The anticipated protective effect of cholesterol-lowering drugs on AMD could not be 
substantiated [54]. A protective effect on AMD was demonstrated in participants using a diet rich of antioxidants and zinc intake in our study population. Support for a multifactorial origin of AMD was found in the cumulative effects of aberrant CFH and CRP genes, inflammations and smoking as genetic and environmental stimulators of the complement cascade [55].

The prevalence estimates of POAG in Rotterdam was highly dependent on the applied criteria [56]. That was a major reason for proposing a classification system without final, subjective adjudication [57]. Systemic blood pressure and hypertension were associated with elevated intraocular pressure but not with prevalent POAG [58]. Relatives of patients with POAG have a strongly increased risk of glaucoma. Enlarged cup-disc ratio was the earliest and most prominent feature of familial aggregation [59]. The incidence of OAG rises significantly with age. Most of the patients with incident OAG were unaware of having OAG [60]. The incidence of visual field loss rises fivefold between 55 and 80 years to 20/1,000 person years in the general population [61]. Glaucoma is the main cause for visual field loss, followed by stroke [62].

Larger retinal venular diameters are associated with generalized atherosclerosis, inflammation and cholesterol levels. Retinal venular diameters are variable and may play their own independent role in predicting cardiovascular disorders [62]. Dilated retinal venules at baseline were predictive for stroke, cerebral infarction, dementia, white brain matter lesions, impaired glucose tolerance, diabetes mellitus and mortality [63, 64]. In systemic hypertension, the arteriolar diameters are narrow and arteriolar and venular narrowing precedes the onset of hypertension [65].

\section{Methods update}

Repeated ophthalmic measurements include best corrected ETDRS visual acuity, refractive error, Goldmann applanation tonometry, keratometry, slitlamp examination of the anterior segment and visual field testing. In pharmacological mydriasis we make colour photographs of the lens, 35 degree photography of the macular area, and simultaneous stereoscopic imaging of the optic disc and macular area. Digital photography of the macular area and optic disc are added since the fourth follow-up examination. Scanning laser ophthalmoscopy (HRT II) measurements of the optic disc, macular pigment density measurements and optical coherence tomography of the macular area and optic disc were added during follow-up.

For the assessment of AMD we use stereoscopic $35^{\circ}$ macular images centred on the fovea. The images are graded according to the International Classification and Grading System for AMD [66].

The procedure for assessing POAG includes Goldmann applanation tonometry, visual field screening, ophthalmoscopy and stereoscopic fundus photography [57].

Assessment of retinal vascular diameters is done by analyses of digitized fundus transparencies with a semi automated system [58, 67].

\section{Genetic studies}

\section{Objectives}

The first objective of the laboratory team is to collect, store and manage the biological tissues sampled in the Rotterdam Study. The second objective of the group concerns genotyping and assessment of biomarkers.

\section{Major findings}

Both from biomarker studies as well as molecular genetic studies important findings have emerged. For example, among the biomarker analyses the study documenting the relationship between homocysteine and osteoporosis has been novel [68] and since widely replicated. Several candidate gene studies have also yielded major new insights coming from both exploratory studies as well as from collaborative replication efforts across all disease-oriented research lines in the Rotterdam Study. A unique feature of the Rotterdam Study is exploited by studying the relationship between pleiotropic gene variants and not one but multiple diseases and disease-related endpoints. For example, the studies on the promoter region of the IGF-1 gene revealed a series of consistent associations ranging from birth weight to diabetes [69], while other consistent associations involve the estrogen receptor alpha (ESR1) gene in relation to osteoporosis [70], osteoarthritis, height, myocardial infarction [5], age-at-menopause, and depression.

The Rotterdam Study is involved as a major collaborative centre for studies for novel genes coming from genome-wide analysis (GWA) studies, including $\mathrm{CFH}$ in age-related macula degeneration [71], NOS1AP in QT interval [72], and several SNPs involved in height, type 2 diabetes, and breast cancer. Finally, Rotterdam Study investigators play a leading role in the emerging large global consortia focussing on the contribution of complex disease gene variants by prospective meta-analyses across many epidemiological cohorts, such as for osteoporosis in the GENOMOS Study and EUROSPAN. 
Methods update

\section{Data collection, storage and management}

At each examination, blood, serum, plasma (citrate, heparine and EDTA based), sputum, and urine are collected. Fasting blood samples are collected along with challenged samples as part of a glucose tolerance test. Sputum is collected before and after a dexamethasone-suppression test. Sputum is frozen at $-196^{\circ} \mathrm{C}$ before and after the challenge and stored at $-80^{\circ} \mathrm{C}$. To obtain serum and plasma, tubes are centrifuged according to a protocol standardising time and conditions from the drawing of blood to centrifugation. All samples are snap frozen at $196^{\circ} \mathrm{C}$ using liquid nitrogen and stored at $-80^{\circ} \mathrm{C}$. RNA is isolated from blood within $5 \mathrm{~h}$ after sampling and stored at $-20^{\circ} \mathrm{C}$. DNA is isolated from blood and extraction has been recently automated using a Hamilton STAR pipetting platform and AGOWA magnetic bead technology. DNA sample storage is in Matrix 2D-barcode tubes in 96-well format. Overnight urine samples are collected, frozen at $196^{\circ} \mathrm{C}$ and stored at $-80^{\circ} \mathrm{C}$. For data management, an inhouse customized laboratory management system has been developed. Sample retrieval will be automated with an inhouse customized laboratory track and trace system.

\section{Blood assessments}

For all participants, serum cholesterol, HDL, LDL, triglycerides, glucose and glucose levels are assessed. In urine, micro albumin and creatinine are determined in all participants. There have been a large number of specific blood/serum/plasma-based biomarker assessments including steroids (e.g. estrogens, androgens, vitamin D, cortisol), interleukins, CRP, IGF1, insulin, iron-parameters (iron, ferritin and transferrin saturation), fibrinogen, homocysteine, folic acid, riboflavine, pyridoxine, SAM/SAH ratio, cobalamine, Lp-PLA2, Fas/Fas-L, vitamins, a-beta42/40 and thyroid hormones (TSH).

\section{Genotyping facilities}

Affiliated laboratory facilities include a medium/highthroughput platform for candidate gene studies and genome wide association (GWA) analyses. The facilities use highend automated machinery including a Caliper/Zymark ALH 3000 pipetting robot (including a TwisterII, and integrated plate sealer, plate reader (OD 260/280), a Tecan EVO 150 Freedom pipetting robot, a Deerac Equator NS808 nanoliter liquid dispenser, 15 electronic PCR machines (ABI 9700, $2 \times 384$ ), an ABI7900HT Taqman machine (running $1 \mathrm{ng}$ gDNA in $2 \mu \mathrm{l}$ reactions), a WAVE 3500HT dHPLC, and two ABI3100 sequencing machines. DNA sample handling is centred on 384-well plates. Candidate gene studies are done mostly using Taqman genotyping with throughputs at 30,000 genotypes per day. Continuous efforts are focussed on reducing the required amount of genomic DNA, which is now down to $1 \mathrm{ng}$ per genotype. Genome-wide genotyping studies are based on 500/1,000 K Affymetrix arrays and 317, 550 and 1,000 K Illumina arrays with throughputs at 100-300 arrays per week.

The genotyping facility has been partly sponsored by NWO investment grants (911-03-012; 175.010.2005.011), is part of the ErasmusMC Biomics core facility, and serves as knowledge centre for polymorphism analysis attracting national and international interested parties, both academic and industrial.

\section{Candidate gene studies}

We have genotyped $>200$ polymorphisms across the complete cohort and conducted a large number of candidate gene studies in the Rotterdam Study. These mostly concern individual potentially functional single nucleotide polymorphisms (SNPs) per gene, but sometimes also haplotype tagging SNPs (e.g. ESR1, ESR2, HSD11B1, fibrinogen), and also high-density SNP screening (e.g. the vitamin D receptor gene [73]). The candidate genes studied include the apolipoprotein E gene (APOE), the angiotensin-converting enzyme (ACE), the gene encoding angiotensinogen (AGT), angiotensin II type 1 receptor (AT1R) gene, G protein beta3 (GNB3), adducine gene, Cholesteryl Ester Transfer Protein (CETP), Hepatic Lipase, Phosphodiesterase 4D (PDE4D), ALOX5AP encoding 5lipoxygenase activating protein, a polymorphism in the regulatory region of the Insulin-like Growth Factor 1 (IGF1) gene, the hemochromatosis (HFE) gene, Complement factor $\mathrm{H}$ gene $(\mathrm{CFH})$, and several polymorphisms in genes from the estrogen-, thyroid-, cortisol-, vitamin D-, IGF-, and Wnt-signalling pathways, the homocysteine pathway, and several matrix molecules.

\section{Genome wide association (GWA) studies}

A recently developed approach to identify robust genetic factors for complex disease is the Genome Wide Association (GWA) analysis. This is based on genotyping epidemiological cohorts with ultra-high density SNP arrays with up to 1 million SNPs. The method has already been shown to successfully identify genetic factors for several traits and diseases including age-related macula 
degeneration, inflammatory bowel disease, body mass index, type 2 diabetes and breast cancer. Through a large grant from the Dutch research organization NWO one of the world's largest GWA studies is conducted involving 10,000 DNA samples from the Rotterdam Study. This GWA is based on the Illumina $550 \mathrm{~K}$ arrays and finished by the end of 2007. The GWA data will be useful for all research lines within the Rotterdam Study, and will also serve as a control GWA dataset for other research centres in and outside the Netherlands for both SNP frequencies as well as copy number variations (CNVs). In addition to this, a pilot study has been performed on 500 women from the Rotterdam Study using the Affymetrix $500 \mathrm{~K}$ platform allowing direct platform comparisons and merging of data to further increase genome coverage. In addition, our group has been active in developing new software for GWA analyses [74].

\section{Pharmaco-epidemiologic studies}

\section{Objectives}

A major objective of the pharmaco-epidemiologic studies is to investigate the role of drugs as determinants of disease in the Rotterdam Study. This includes studying efficacy and effectiveness of drugs, as well as adverse reactions to drugs.

\section{Major findings}

Important findings have been published on pharmaco-epidemiological topics concerning the main outcomes in the Rotterdam Study. Studies about the association between dementia and antihypertensive drugs [75] and NSAIDs [26] have strongly suggested a protective effect of both groups of drugs. Several studies have been performed on cardiovascular topics [76-78]. In one of these studies, NSAIDs were associated with an increased risk of heart failure [79]. In line with the suspicion that QTc-prolonging drugs may cause sudden cardiac death, it was demonstrated in the Rotterdam Study that a prolonged QTc is indeed an important risk factor [77]. Furthermore, in one study it was demonstrated that high-dose corticosteroids increase the risk of atrial fibrillation [78]. In the important area of locomotor diseases, studies have demonstrated that thiazide diuretics protect against hip fracture [79] and that statins reduce the risk of vertebral fracture [80]. On the other hand, the risk that long-term use of certain NSAIDs may aggravate signs of osteoarthritis has been emphasized [81]. In the area of ophthalmological diseases, a protective effect of cholesterol-lowering agents on macular degeneration has been suggested [82]. In other areas, such as pharmacogenetics and other causes of interactions between drugs, several important findings have been published [83-91].

Methods update

For several reasons, a drug is a highly attractive determinant in clinical epidemiology. First, drugs are probably the most important therapeutic intervention in health care. Despite rigorous clinical research before registration, many important effects of drugs are discovered after marketing. Second, all marketed drugs have proven biological activity, meaning that it concerns a determinant which really matters. Third, and as a consequence of the availability of complete medication histories in Dutch health care, the role of drug exposure can be assessed in a detailed way.

In the Rotterdam Study, there is an almost complete coverage of the population as of 1 January, 1991 thanks to the fact that all pharmacies which serve the Ommoord region are on one computer network. To date, almost 3 million prescriptions have been delivered to the population of the Rotterdam Study and of each prescription, details are available about the product name and contents, ATC-code, dosage and duration of drug therapy.

Drugs are a group of determinants, which can be studied in association with a large variety of diseases. In the Rotterdam Study, there is a strong interest in the association between drugs and the cardiovascular, neurological, endocrinological and ophthalmological diseases, which have been the main topics since starting. However, there is also important information about the association with psychiatric diseases, cancer, and chronic obstructive pulmonary disease. Moreover, important information about secondary outcomes, such as drug blood levels, other laboratory information, and information about hospital discharge diagnoses, is gathered on a continuous basis to facilitate pharmaco-epidemiological studies.

\section{Management of the Rotterdam Study}

The Rotterdam Study is directed by a Management Team comprising Jan Heeringa, MD, study coordinator, Eric Neeleman, head IT, Frank van Rooij, head data-management, and the scientific principal investigators Albert Hofman (PI Rotterdam Study, chairman), Monique Breteler (PI Neurological diseases), Cornelia van Duijn (PI Genetic studies), Gabriel Krestin (PI Radiology), Huibert Pols (PI Endocrinology), Bruno Stricker (PI Pharmacoepidemiology), Henning Tiemeier (PI Psychiatric diseases), André Uitterlinden (PI Genome wide analysis), Johannes Vingerling (PI Ophthalmologic diseases) and Jacqueline Witteman (PI Cardiovascular diseases). 
Acknowledgement The Rotterdam Study is supported by the Erasmus Medical Center and Erasmus University Rotterdam, the Netherlands Organization for Scientific Research (NWO), the Netherlands Organization for Health Research and Development (ZonMw), the Research Institute for Diseases in the Elderly (RIDE), the Ministry of Education, Culture and Science, the Ministry of Health, Welfare and Sports, the European Commission (DG XII), and the Municipality of Rotterdam. The contribution of inhabitants, general practitioners and pharmacists of the Ommoord district to the Rotterdam Study is greatly acknowledged.

\section{References}

1. Oeppen J, Vaupel JW. Broken limits to life expectancy. Science 2002;296:1029-31.

2. Peto R, Doll R. There is no such thing as aging. BMJ 1997;315:1030-2.

3. Hofman A, Grobbee DE, de Jong PTVM, van den Ouweland FA. Determinants of disease and disability in the elderly: the Rotterdam Study. Eur J Epidemiol 1991;7:403-22.

4. Hak AE, Pols HAP, Visser TJ, Drexhage HA, Hofman A, Witteman JCM. Subclinical hypothyroidism is an independent risk factor for atherosclerosis and myocardial infarction in elderly women: the Rotterdam Study. Ann Intern Med 2000;132:270-8.

5. Schuit SCE, Oei HHS, Witteman JCM, Geurts Van Kessel CH, Van Meurs JBJ, Nijhuis RL, Van Leeuwen JPTM, De Jong FH, Zillekens MC, Hofman A, Pols HAP, Uitterlinden AG. Estrogen receptor $\alpha$ gene polymorphisms and risk of myocardial infarction. JAMA 2004;291:2969-77.

6. Kardys I, De Maat MP, Uitterlinden AG, Hofman A, Witteman JC. C-reactive protein gene haplotypes and risk of coronary heart disease. The Rotterdam Study. Eur Heart J 2006;27:1331-7.

7. Oei HH, Van der Meer IM, Hofman A, Koudstaal PJ, Stijnen T, Breteler MM, Witteman JC. Lipoprotein-associated phospholipase A2 activity is associated with risk of coronary heart disease and ischemic stroke: the Rotterdam Study. Circulation 2005;111:570-5.

8. Kardys I, Klaver CC, Despriet DD, Bergen AA, Uitterlinden AG, Hofman A, Oostra BA, Van Duijn CM, De Jong PT, Witteman JC. A common polymorphism in the complement factor $\mathrm{H}$ gene is associated with increased risk of myocardial infarction. The Rotterdam Study. J Am Coll Cardiol 2006;47:1568-75.

9. Van der Meer IM, Bots ML, Hofman A, del Sol AI, van der Kuip DA, Witteman JC. Predictive value of noninvasive measures of atherosclerosis for incident myocardial infarction: the Rotterdam Study. Circulation 2004;109:1089-94.

10. Mattace-Raso FUS, Van der Cammen TJM, Hofman A, Van Popele NM, Bos ML, Schalekamp MADH, Asmar R, Reneman RS, Hoeks A, Breteler MMB, Witteman JCM. Arterial stiffness and risk of coronary heart disease and stroke. The Rotterdam Study. Circulation 2006;113:657-63.

11. Vliegenthart R, Oudkerk M, Hofman A, Oei HHS, van Dijck W, van Rooij F, Witteman JCM. Coronary calcification improves cardiovascular risk prediction in a population of older adults. Circulation 2005;112:572-7.

12. Bleumink GS, Knetsch AM, Sturkenboom MC, Straus SM, Hofman A, Deckers JW, Witteman JC, Stricker BH. Quantifying the heart failure epidemic: prevalence, incidence rate, lifetime risk and prognosis of heart failure the Rotterdam Study. Eur Heart J 2004;25:1614-9.

13. Heeringa J, van der Kuip DA, Hofman A, Kors JA, van Herpen G, Stricker BH, Stijnen T, Lip GY, Witteman JC. Prevalence, incidence and lifetime risk of atrial fibrillation: the Rotterdam study. Eur Heart J 2006;27:949-53.
14. Heeringa J, van der Kuip DAM, Hofman A, Kors JA, van Rooij FJA, Lip GYH, Witteman JCM. Subclinical atherosclerosis and risk of atrial fibrillation. Arch Intern Med 2007;167:382-7.

15. Van Vark LC, Kardys I, Bleumink GS, Knetsch AM, Deckers JW, Hofman A, Stricker BH, Witteman JC. Lipoprotein-associated phospholipase A2 activity and risk of heart failure: the Rotterdam study. Eur Heart J 2006;27:2346-52.

16. Ott A, Breteler MMB, van Harskamp F, Claus JJ, van der Cammen TJM, Grobbee DE, Hofman A. Prevalence of Alzheimer's disease and vascular dementia: association with education. The Rotterdam study. BMJ 1995;310:970-3.

17. de Rijk MC, Breteler MMB, Graveland GA, Ott A, Grobbee DE, van der Meché FGA, Hofman A. Prevalence of Parkinson's disease in the elderly. The Rotterdam Study. Neurology 1995;45:2143-6.

18. Ruitenberg A, Ott A, van Swieten JC, Hofman A, Breteler MMB. Incidence of dementia: does gender make a difference? Neurobiol Aging 2001;22:575-80.

19. de Lau LML, Giesbergen PCLM, de Rijk MC, Hofman A, Koudstaal PJ, Breteler MMB. Incidence of parkinsonism and Parkinson's disease in a general population: the Rotterdam Study. Neurology 2004;63:1240-4.

20. Hollander M, Koudstaal PJ, Bots ML, Grobbee DE, Hofman A, Breteler MMB. Incidence, risk and case fatality of first ever stroke in the elderly population. The Rotterdam Study. J Neurol Neurosurg Psychiatry 2003;74:317-21.

21. Breteler MMB, Claus JJ, Grobbee DE, Hofman A. Cardiovascular disease and the distribution of cognitive function in an elderly population. The Rotterdam Study. BMJ 1994;308:1604-8.

22. Hofman A, Ott A, Breteler MMB, Bots ML, Slooter AJC, van Harskamp F, van Duijn CM, van Broeckhoven C, Grobbee DE. Atherosclerosis, apolipoprotein $\mathrm{E}$ and the prevalence of dementia and Alzheimer's disease in the Rotterdam Study. Lancet 1997;349:151-4.

23. Ott A, Slooter AJC, Hofman A, van Harskamp F, Witteman JCM, van Broeckhoven C, van Duijn CM, Breteler MMB. Smoking and risk of dementia and Alzheimer's disease in a population-based cohort study: the Rotterdam Study. Lancet 1998;351:1840-3.

24. Engelhart MJ, Geerlings MI, Ruitenberg A, van Swieten JC, Hofman A, Witteman JCM, Breteler MMB. Dietary intake of antioxidants and risk of Alzheimer's disease: the Rotterdam Study. JAMA 2002;287:3223-9.

25. Ruitenberg A, van Swieten JC, Witteman JCM, Mehta KM, van Duijn CM, Hofman A, Breteler MMB. Alcohol consumption and risk of dementia: the Rotterdam Study. Lancet 2002;359:281-6.

26. In 't Veld BA, Ruitenberg A, Launer LJ, van Duijn CM, Hofman A, Stijnen Th, Breteler MMB, Stricker BHCh. NSAID and the risk of Alzheimer's disease or vascular dementia. The Rotterdam Study. N Engl J Med 2001;345:1515-21.

27. Hollander M, Bots ML, Iglesias del Sol A, Koudstaal PJ, Witteman JCM, Grobbee DE, Hofman A, Breteler MMB. Carotid plaques increase the risk of stroke and subtypes of cerebral infarction in asymptomatic elderly: the Rotterdam Study. Circulation 2002;105:2872-7.

28. Bos MJ, Schipper CMA, Koudstaal PJ, Witteman JCM, Hofman A, Breteler MM. High plasma C-reactive protein level is not an independent predictor for stroke. The Rotterdam Study. Circulation 2006;114:1591-8.

29. Vermeer SE, den Heijer T, Prins ND, Hofman A, Koudstaal PJ, Breteler MMB. Silent brain infarcts and the risk of dementia and cognitive decline. The Rotterdam Scan Study. N Engl J Med 2003;348:1215-22.

30. Vernooij MW, Ikram MA, Tanghe HL, Vincent AJPE, Hofman A, Krestin GP, Niessen WJ, Breteler MMB, Van der Luyt A. Incidental findings on brain MRI in the general population $\mathrm{N}$ Engl J Med 2007 (in press). 
31. de Groot JC, de Leeuw FE, Oudkerk M, Hofman A, Jolles J, Breteler MMB. Cerebral white matter lesions and depressive symptoms in elderly adults. Arch Gen Psychiatry 2000;57: $1071-6$.

32. Den Heijer T, Geerlings MI, Hoebeek FE, Hofman A, Koudstaal PJ, Breteler MMB. Use of hippocampal and amygdalar volumes on MRI to predict dementia in cognitively intact elderly people. Arch Gen Psychiatry 2006;63:57-62.

33. Breteler MMB, van Swieten JC, Bots ML, Grobbee DE, Claus JJ, van den Hout JHW, van Harskamp F, Tanghe HLJ, de Jong PTVM, van Gijn J, Hofman A. Cerebral white matter lesions, vascular risk factors and cognitive function in a population-based study. Neurology 1994;44:1246-52.

34. Tiemeier H, Dijck van W, Hofman A, Witteman JCM, Stijnen T, Breteler MMB. Atherosclerosis and late life depression are related. The Rotterdam Study. Arch Gen Psychiatry 2004;61:369-76.

35. Tiemeier H, Bakker SLM, Hofman A, Koudstaal PJ, Breteler MMB. Cerebral haemodynamics and depression in the elderly. J Neurol Neurosurg Psychiatry 2002;73:34-39.

36. Naarding P, Tiemeier H, Breteler MM, Schoevers RA, Jonker C, Koudstaal PJ, Beekman AT. Clinically defined vascular depression in the general population. Psychol Med 2007;37:383-92.

37. Tiemeier H, van Tuijl HR, Hofman A, Kiliaan AJ, Breteler MMB. Plasma fatty acid composition and depression in the elderly are associated: the Rotterdam Study. Am J Clin Nutr 2003;78:40-6.

38. Tiemeier H, van Tuijl HR, Hofman A, Meijer J, Kiliaan AJ, Breteler MMB. Vitamin B12, folate, and homocysteine in depression: the Rotterdam Study. Am J Psychiatry 2002;159:2099-101.

39. Tiemeier H, Hofman A, Kiliaan AJ, Meijer J, Breteler MMB. Vitamin E and depressive symptoms are not related. The Rotterdam Study. J Affect Disord 2002;72:79-83.

40. Tiemeier H, Hofman A, van Tuijl HR, Kiliaan AJ, Meijer J, Breteler MMB. Inflammatory proteins and depression in the elderly. Epidemiology 2003;14:103-7.

41. Tiemeier H, Schuit SC, den Heijer T, van Meurs JB, van Tuijl HR, Hofman A, Breteler MM, Pols HA, Uitterlinden AG. Estrogen receptor alpha gene polymorphisms and anxiety disorder in an elderly population. Mol Psychiatry 2005;10:806-7.

42. Radloff LS. The CES-D scale: a self-report depression scale for research in the general population. Appl Psychol Meas 1977;1:385-410.

43. Wing JK, Babor T, Brugha T, Burke J, Cooper JE, Giel R. Scan: schedules for clinical assessment in neuropsychiatry. Arch Gen Psychiatry 1990;47:589-93.

44. Wittchen HU, Lachner G, Wunderlich U, Pfister H. Test-retest reliability of the computerized DSM-IV version of the MunichComposite International Diagnostic Interview (M-CIDI). Soc Psychiatry Psychiatr Epidemiol 1998;33:568-78.

45. van den Berg JF, Tulen JHM, Neven AK, Hofman A, Miedema HME, Witteman JCM, Tiemeier H. Sleep duration and hypertension are not associated in the elderly. Hypertension 2007;50:585-9.

46. Prigerson HG, Maciejewski PK, Reynolds CF 3rd, Bierhals AJ, Newsom JT, Fasiczka A, Frank E, Doman J, Miller M. Inventory of complicated grief: a scale to measure maladaptive symptoms of loss. Psychiatry Res 1995;59:65-79.

47. Klaver CC, Wolfs RC, Vingerling JR, Hofman A, de Jong PT. Age-specific prevalence and causes of blindness and visual impairment in an older population: the Rotterdam Study. Arch Ophthalmol 1998;116:653-8.

48. Vingerling JR, Hofman A, Grobbee DE, de Jong PT. Age-related macular degeneration and smoking. The Rotterdam Study. Arch Ophthalmol 1996;114:1193-6.
49. Vingerling JR, Dielemans I, Bots ML, Hofman A, Grobbee DE, de Jong PT. Age-related macular degeneration is associated with atherosclerosis. The Rotterdam Study. Am J Epidemiol 1995;142:404-9.

50. Ikram MK, van Leeuwen R, Vingerling JR, Hofman A, de Jong PT. Relationship between refraction and prevalent as well as incident age-related maculopathy: the Rotterdam Study. Invest Ophthalmol Vis Sci 2003;44:3778-82.

51. Klaver CC, Kliffen M, van Duijn CM, et al. Genetic association of apolipoprotein $\mathrm{E}$ with age-related macular degeneration. Am $\mathrm{J}$ Hum Genet 1998;63:200-6.

52. Klaver CC, Wolfs RC, Assink JJ, van Duijn CM, Hofman A, de Jong PT. Genetic risk of age-related maculopathy. Populationbased familial aggregation study. Arch Ophthalmol 1998;116:1646-51.

53. Assink JJ, Klaver CC, Houwing-Duistermaat JJ, et al. Heterogeneity of the genetic risk in age-related macular disease: a population-based familial risk study. Ophthalmology 2005; 112:482-7.

54. van Leeuwen R, Vingerling JR, Hofman A, de Jong PT, Stricker $\mathrm{BH}$. Cholesterol lowering drugs and risk of age related maculopathy: prospective cohort study with cumulative exposure measurement. BMJ 2003;326:255-6.

55. Despriet DD, Klaver CC, Witteman JC, et al. Complement factor $\mathrm{H}$ polymorphism, complement activators, and risk of age-related macular degeneration. JAMA 2006;296:301-9.

56. Dielemans I, Vingerling JR, Wolfs RC, Hofman A, Grobbee DE, de Jong PT. The prevalence of primary open-angle glaucoma in a population-based study in The Netherlands. The Rotterdam Study. Ophthalmology 1994;101:1851-5.

57. Wolfs RC, Borger PH, Ramrattan RS, et al. Changing views on open-angle glaucoma: definitions and prevalences: the Rotterdam Study. Invest Ophthalmol Vis Sci 2000;41:3309-21.

58. Dielemans I, Vingerling JR, Algra D, Hofman A, Grobbee DE, de Jong PT. Primary open-angle glaucoma, intraocular pressure, and systemic blood pressure in the general elderly population. The Rotterdam Study. Ophthalmology 1995;102:54-60.

59. Wolfs RC, Klaver CC, Ramrattan RS, van Duijn CM, Hofman A, de Jong PT. Genetic risk of primary open-angle glaucoma. Population-based familial aggregation study. Arch Ophthalmol 1998;116:1640-5.

60. de Voogd S, Ikram MK, Wolfs RC, Jansonius NM, Hofman A, de Jong PT. Incidence of open-angle glaucoma in a general elderly population: the Rotterdam Study. Ophthalmology 2005; 112:1487-93.

61. Skenduli-Bala E, de Voogd S, Wolfs RC, et al. Causes of incident visual field loss in a general elderly population: the Rotterdam study. Arch Ophthalmol 2005;123:233-8.

62. Ikram MK, de Jong FJ, Vingerling JR, et al. Are retinal arteriolar or venular diameters associated with markers for cardiovascular disorders? The Rotterdam Study. Invest Ophthalmol Vis Sci 2004:45:2129-34.

63. Rietveld I, Ikram MK, Vingerling JR, et al. An igf-I gene polymorphism modifies the risk of diabetic retinopathy. Diabetes 2006;55:2387-91.

64. Ikram MK, de Jong FJ, Bos MJ, et al. Retinal vessel diameters and risk of stroke: the Rotterdam Study. Neurology 2006;66:1339-43.

65. Ikram MK, Witteman JC, Vingerling JR, Breteler MM, Hofman A, de Jong PT. Retinal vessel diameters and risk of hypertension: the Rotterdam Study. Hypertension 2006;47:189-94.

66. Bird AC, Bressler NM, Bressler SB, et al. An international classification and grading system for age-related maculopathy and age-related macular degeneration. The International ARM Epidemiological Study Group. Surv Ophthalmol 1995;39: $367-74$. 
67. Hubbard LD, Brothers RJ, King WN, et al. Methods for evaluation of retinal microvascular abnormalities associated with hypertension/sclerosis in the Atherosclerosis Risk in Communities Study. Ophthalmology 1999;106:2269-80.

68. van Meurs JB, Dhonukshe-Rutten RA, Pluijm SM, van der Klift M, de Jonge R, Lindemans J, de Groot LC, Hofman A, Witteman JC, van Leeuwen JP, Breteler MM, Lips P, Pols HA, Uitterlinden AG. Homocysteine levels and the risk of osteoporotic fracture. $\mathrm{N}$ Engl J Med 2004;350:2033-41.

69. Vaessen N, Janssen JA, Heutink P, Hofman A, Lamberts SW, Oostra BA, Pols HA, van Duijn CM. Association between genetic variation in the gene for insulin-like growth factor-I and low birthweight. Lancet 2002;359:1036-7.

70. van Meurs JBJ, Schuit SCE, Weel AEAM, van der Klift M, Bergink AP, Arp PP, Colin EM, Fang Y, Hofman A, van Duijn CM, van Leeuwen JPTM, Pols HAP, Uitterlinden AG. Association of $5^{\prime}$ estrogen receptor alpha gene polymorphisms with bone mineral density, vertebral bone area, and fracture risk. Hum Mol Genet 2003;12:1745-54.

71. Despriet DD, Klaver CC, Witteman JC, Bergen AA, Kardys I, de Maat MP, Boekhoorn SS, Vingerling JR, Hofman A, Oostra BA, Uitterlinden AG, Stijnen T, van Duijn CM, de Jong PT. Complement factor $\mathrm{H}$ polymorphism, complement activators, and risk of age-related macular degeneration. JAMA 2006;296:301-9.

72. Aarnoudse AJLHJ, Newton-Cheh C, de Bakker PIW, Straus SMJM, Kors JA, Hofman A, Uitterlinden AG, Witteman JCM, Stricker BHCh. A common NOS1AP variant is associated with longer QTc interval and sudden cardiac death: the Rotterdam Study. Circulation 2007;116:10-6.

73. Fang Y, van Meurs JB, d'Alesio A, Jhamai M, Zhao H, Rivadeneira F, Hofman A, van Leeuwen JP, Jehan F, Pols HA, Uitterlinden AG. Promoter and $3^{\prime}$ UTR haplotypes in the vitamin $\mathrm{D}$ receptor gene predispose to osteoporotic fracture: the Rotterdam Study Am J Hum Genet 2005;77:807-23.

74. Aulchenko YS, Ripke S, Isaacs A, van Duijn CM. GenABEL: an $\mathrm{R}$ library for genome-wide association analysis. Bioinformatics 2007 (in press).

75. In 't Veld BA, Ruitenberg A, Hofman A, Stricker BHCh, Breteler MMB. Antihypertensive drugs and incidence of dementia: the Rotterdam study. Neurobiol Aging 2001;22:407-12.

76. Feenstra J, Heerdink ER, Grobbee DE, Stricker BHCh. Association of nonsteroidal anti-inflammatory drugs with first occurrence of heart failure and with relapsing heart failure. Arch Int Med 2002;162:265-70.

77. Straus SM, Kors JA, de Bruin ML, van der Hooft CS, Hofman A, Heeringa J, Deckers JW, Kingma JH, Sturkenboom JCM, Stricker $\mathrm{BHCh}$, Witteman JCM. Prolonged QTc interval and risk of sudden cardiac death in a population of older adults. J Am Coll Cardiol 2006;47:362-7.

78. Van der Hooft CS, Heeringa J, Brusselle GG, Hofman A, Witteman JCM, Kingma JH, Sturkenboom MCJM, Stricker BHCh. Corticosteroids and the risk of atrial fibrillation. Arch Int Med 2006;165:1016-20.

79. Schoofs MWCJ, van der Klift M, Hofman A, de Laet CEDH, Herings RMC, Stijnen Th, Pols HAP, Stricker BHCh. Thiazide diuretics and the risk for hip fracture. Ann Intern Med 2003;139:476-82.
80. Schoofs MW, Sturkenboom MCJM, van der Klift M, Hofman A, Pols HA, Stricker BHCh. HMG-CoA reductase inhibitors and the risk of vertebral fracture. J Bone Miner Res 2004;19:1525-30.

81. Reijman M, Bierma-Zeinstra SM, Pols HAP, Koes BW, Stricker $\mathrm{BHCh}$, Hazes JM. Is there an association between the use of different types of NSAIDs and radiologic progression of osteoarthritis? The Rotterdam Study. Arthritis Rheum 2005;52: 3137-42.

82. Van Leeuwen R, Vingerling JR, Hofman A, de Jong PTVM, Stricker BHCh. Cholesterol lowering drugs and risk of age related maculopathy: prospective cohort study with cumulative exposure measurement. BMJ 2003;326:255-6.

83. Visser LE, Penning-van Beest FJA, Kasbergen AAH, De Smet PAGM, Vulto AG, Hofman A, Stricker BHCh. Overanticoagulation associated with combined use of antifungal agents and coumarin anticoagulants. Clin Pharmacol Ther 2002;71:496-502.

84. Visser LE, Penning-van Beest FJA, Kasbergen HAA, De Smet PAGM, Vulto AG, Hofman A, Stricker BHCh. Overanticoagulation associated with combined use of antibacterial agents and acenocoumarol or phenprocoumon anticoagulants. Thromb Haemost 2002;88:705-10.

85. Visser LE, van Vliet M, van Schaik RHN, Kasbergen AAH, de Smet PAGM, Vulto AG, Hofman A, van Duijn CM, Stricker $\mathrm{BHCh}$. The risk of overanticoagulation in patients with cytochrome $\mathrm{P} 450 \mathrm{CYP} 2 \mathrm{C} 9 * 2$ or CYP2C9*3 alleles on acenocoumarol or phenprocoumon. Pharmacogenetics 2004; 14:27-33.

86. Visser LE, Penning-van Beest FJ, Wilson JHP, Vulto AG, Kasbergen AA, de Smet PAGM, Hofman A, Stricker BHCh. Overanticoagulation associated with combined use of lactulose and coumarin anticoagulants. Br J Clin Pharmacol 2004;57:5224.

87. Visser LE, van Schaik RH, van Vliet M, Trienekens PH, de Smet PAGM, Vulto AG, Hofman A, van Duijn CM, Stricker BHCh. The risk of bleeding complications in patients with cytochrome P450 CYP2C9*2 or CYP2C9*3 alleles on acenocoumarol or phenprocoumon. Thromb Haemost 2004;92:61-6.

88. Visser LE, Bleumink GS, Trienekens PH, Vulto AG, Hofman A, Stricker BHCh. The risk of overanticoagulation in patients with heart failure on coumarin anticoagulants. $\mathrm{Br} \mathrm{J}$ Haematol 2004;127:85-9.

89. Visser LE, van Schaik RHN, van Vliet M, Trienekens PH, de Smet PAGM, Vulto AG, Hofman A, van Duijn CM, Stricker $\mathrm{BHCh}$. Allelic variants of cytochrome P450 2C9 modify the interaction between nonsteroidal anti-inflammatory drugs and coumarin anticoagulants. Clin Pharmacol Ther 2005;77:479-85.

90. Bleumink GS, Schut AF, Sturkenboom MC, van Duijn CM, Deckers JW, Hofman A, Kingma JH, Witteman JC, Stricker BHCh. Mortality in patients with hypertension on ACE-inhibitor treatment is influenced by the ACE I/D polymorphism. Pharmacogenet Genomics 2005;15:75-81.

91. Visser LE, Trienekens PH, de Smet PAGM, Vulto AG, Hofman A, van Duijn CM, Stricker BHCh. Patients with an ApoE epsilon4 allele require lower doses of coumarin anticoagulants. Pharmacogenet Genomics 2005;15:69-74. 